\title{
The Influential Knowledge Factors of Companies' Performance in Slovenia
}

\section{Katja Rašič}

Ministry of Infrastructure, Slovenia

Matjaž Mulej, Vesna Čančer

University of Maribor, Faculty of Economics and Business, Slovenia

\section{Abstract}

Background: Knowledge plays a crucial role in supporting the European Union model based on economic growth, social responsibility, and sustainable development. To improve companies' performance, one must reflect on new forms of knowledge and develop new indicators to measure them. Objectives: The goal of the paper is to investigate the impact of the selected factors of knowledge on companies' performance in Slovenia. Methods/Approach: A questionnaire was created and sent to small and medium-sized enterprises in Slovenia. The principle axis factoring method was used to identify the factors of knowledge and of companies' performance, and a regression analysis was conducted to determine the influence of the selected knowledge factors on companies' performance. Results: The establishment of scientists' collaboration with companies has a positive impact on companies' performance, but the obstacles to the establishment of scientists' collaboration with companies do not have any impact. Conclusions: The results could be useful for governments and companies in the adoption of measures aimed at strengthening scientists' collaboration with companies. Further research can be oriented toward the common synergy index (e.g., the knowledge triangle).

Keywords: company performance; indicator; knowledge; transitional economy; European Union

JEL classification: A12, C83, O1, O3

Paper type: Research article

Received: Dec 02, 2016

Accepted: Feb 02, 2016

Citation: Rašič, K., Mulej, M., Čančer, V. (2016), "The Influential Knowledge Factors of Companies' Performance in Slovenia", Business Systems Research, Vol. 7, No. 1, pp. 46-58.

DOI: 10.1515/bsri-2016-0004

\section{Introduction}

Technology research, innovativeness, and knowledge play a crucial role in dealing with the main problems of the European Union (EU) and in supporting the EU model based on economic growth, social responsibility, and sustainable development (European Union, 2010). The European Research Advisory Board (2007) 
recommended the invigoration of the European knowledge triangle (education, research, and innovation) through the Structural Funds' "Energizing Europe's Knowledge Triangle of Research, Education and Innovation through the Structural Funds". Research, knowledge, and innovation as well as the European knowledge triangle are based on the achievement of these objectives (Council of the European Union, 2007, p. 7). Innovation has a double meaning: it covers the inventioninnovation-diffusion process and its outcome, which is a novelty through which its users find a new source of their new benefit, including their competitiveness. In business, it is officially and theoretically recognized as a key to growth and competitiveness, because it is the basis for the invention-innovation-diffusion process and includes innovation of all contents (European Commission, 2008).

The genuine education of citizens is one of the leading European innovation strategies. The European Institute of Technology (EIT, 2008) has sought to assemble the three leading factors of the knowledge triangle, which includes more successful education, research, and business innovation, at the national governmental level. In light of the increasing capacity stemming from the increasing European education and, consequently, the results of research in a clearly defined marketing opportunity, the innovative European Institute of Technology built a bridge across the gap with the EU's international competitors (European Commission, 2008). Investments in knowledge and innovation in the EU rose to 50 billion euros in Structural Funds from 2007 to 2013. This is almost the same amount as the scientific-research budget of the European Commission (UNESCO 2008).

Ribeiro et al. (2010) found a strong correlation between science and technology and the gross domestic product (GDP). Economic growth depends on scientific and technological resources. The goal of the Lisbon strategy is to transform each EU member state into a modern, dynamic economy with greater-and more economic-knowledge and education (Council of the European Union, 2007). Guellec (1996) considered knowledge to be the central component of the economy, which is refined in innovation and the human capital, investment in intangible capital (research and development), and training in the sense of technological development. Our research is encouraged by the motion for a resolution of the European Parliament (2011) on the "Report on GDP and beyondMeasuring progress in a changing world." Stiglitz et al. (2009), Costanza et al. (2009), and OECD (2015) have also worked toward the same future goal as the European Union, thereby defining indicators that are crucial for the creation of a new growth model to achieve economic growth for a better quality of life of all European citizens. More and more researchers have sought to answer the question as to whether the social goal of raising the GDP, regardless of other costs or the satisfaction of people, makes sense (see, e.g., Stiglitz, 2009; Steiner et al., 2015).

To improve companies' performance, one must measure and reflect new forms of knowledge and develop new indicators to measure them. Emphasizing the areas of knowledge that affect economic growth, this paper presents the research that concentrates on knowledge indicators and their influence on company performance at the micro-economic level, using the Republic of Slovenia as the case (Rašič, 2015). We report how we have defined economic growth as company performance on the microeconomic level of the Republic of Slovenia. The research question is as follows: What areas of knowledge affect company performance and, thus, economic growth at the microeconomic level, and how can we measure these areas? By using the quantitative survey based on random sampling, data about scientists' collaboration with companies and company performance were gathered from a sample of small and medium-sized enterprises. A regression analysis 
based on saved factor scores was used to determine the knowledge factors influential on company performance.

The next section reviews the relevant literature on the knowledge indicators and the influence of knowledge on company performance. The third section encompasses the methodology used for data gathering and preparation, and the fourth section presents the survey results regarding knowledge factors-namely, the establishment of scientists' collaborative efforts with companies and obstacles to such efforts. These factors are discussed in the penultimate section. Limitations, further research possibilities, and final conclusions are drawn in the final section.

\section{Literature review}

Polt et al. (2001) exposed two main objectives of the cooperation between industry and science: to ensure that public investments in higher education spill over to enterprises and to serve as a tool for enterprises to increase their competitiveness by acquiring external knowledge. Pezdir's (2004) research shows that for universities and research institutes, the most important motives for research-developmental cooperation in the Republic of Slovenia are contributions to increasing economic competitiveness, joint application to the national projects, cooperation with industry, and access to potential consumers. For companies, the important motives of cooperation are joint application to the national projects, the fact that they must cooperate with science due to market pressures, and the possibility of applying the latest research equipment available to science. Similarly, the research results of Borell-Damian et al. (2014) clearly demonstrated that motivations for companies to engage in collaborative research partnership with universities are improving not only the capacity of their research and development, but also their competitive advantage. However, Polt et al. (2001) concluded that the performance of the industry-science relationship affects economic performance only to a limited extent. Similarly, Pezdir (2004) noted that the level of cooperation between science and the economy was low.

Reports from the OECD (1996, 2001a, 2001b), APEC (2000), and Eurostat (2008) describe the society of knowledge using the following dimensions: the system of innovation, human capital, information and communication technologies, and the elements of the business environment. They identified the following general indicators to measure the intensity of knowledge in a specific company: the percentage of GDP, developments from knowledge-intensive activities, and the percentage of creative/innovative employees in their workforce. Pavlin et al. (2005) concluded that these indicators complement other, more complex models.

The triple helix of relationships among university, industry, and government (Etzkowitz, 2002, 2008) are modeled on the design of technological policies and the role of the national support in knowledge transfer between science and the economy. Although the role of science is to seek new knowledge and the role of companies is the production of goods, the activities of university, industry, and government overlap.

The research-innovation-education triangle should be strengthened (Council of the European Union, 2008). High-quality education and the increasing and effective investment "in human capital and creativity throughout people's lives are crucial for Europe's success in a globalized world" (Council of the European Union, 2008, p. 9). They can help bridge and facilitate the transition to an economy based on knowledge, increase the employment level and contribute to structural changes. They can also be used to engage poverty, inequality, and youth unemployment. For example, European Commission (2006) presented the following measures of 
innovation policy in the field of knowledge transfer in Sweden: the creation of knowledge for innovation, innovative trade and production, innovation in the public sector, and innovation of individuals.

According to Kotnik (2005), the study of innovation activities raises many questions. Among them, the following questions are key to economic growth: how to explain differences in innovation activity between companies, what are the characteristics of companies and their environment that lead to the diversity of the results of innovation activities, and how the results affect companies' economic performance. Kotnik (2005) concluded that knowledge capital created with innovation activity has a positive effect on productivity only in companies with medium and high intensity, but not in low-tech industries. In addition, the research results of Borell-Damian et al. (2014, p. 12) clearly demonstrated the key role of collaborative research and innovation activities between university and business partners, particularly small and medium-sized enterprises, "in helping to facilitate the economic and social development at the regional level".

Knowledge is not a goal itself. Companies that have knowledge increase their effectiveness and enhance their economic performance. They use financial and non-financial indicators to determine their performance. The balanced performance indicators developed by Kaplan and Norton (1996) can serve as a basis for indicators for assessing company performance.

\section{Methodology}

\section{Data}

The quantitative method of data gathering was used in the survey at the microeconomic level in the Republic of Slovenia. The sample was selected from companies included in the business register of Slovenia, AJPES database iBON 2012 (AJPES, 2012). Units of the sample were spread out based on random sampling, which included 1,430 respondents or employees in small and medium-sized companies of Slovenia. One employee provided data for one company. The questionnaire was posted on the website http://www.1 ka. Data collection took place in June and July 2013, by email. We received 288 completed questionnaires, representing a $20.14 \%$ response rate.

\section{Research instrument}

The questionnaire contains a combination of closed questions with a 7-point Likert type rating scale ranging from 1 (strongly disagree) to 7 (totally agree). Based on the knowledge and company performance literature, we developed indicators and variables created in accordance with the questionnaire. Table 1 shows the structure of the research instrument, together with the literature sources of groups of questions. One set of questions relates to knowledge-namely, scientists' collaboration with companies. Another set of questions relates to company performance in the last two years for the company in which the respondent was employed.

\section{Statistical analysis}

The obtained data were analyzed by using descriptive statistics as well as factor and regression analyses. We examined the suitability of the information for using the factor analysis. For this purpose, we used Bartlett's test of sphericity and then calculated the Kaiser-Meyer-Olkin (KMO) Measure of sampling adequacy. Then we conducted the factor analysis using the principal axis factoring (PAF) method. The basic principle of the PAF method is to maximize the variance of the common 
factor, but based on an estimate of the variances that determines the number of factors (Field, 2005).

Table 1

Research instrument description

Statement Source

\section{Knowledge - scientists' collaboration with companies}

Knowledge is oriented to R\&D

Joint R\&D projects of universities and companies are useful for marketing.

Financing of all project phases is uncertain.

The company lacks financial resources for collaboration with universities.

Governmental policy in the field of research is unclear.

There is a lack of state incentives for scientists' collaboration with companies.

Slovenia is overly oriented to basic research.

Adapted according to

Pezdir (2014)

Habilitation rules of RIs and universities in Slovenia do not motivate collaboration with companies.

There is a lack of researchers in Rls and universities that would meet the specific needs of projects for companies in Slovenia.

There is a lack of interoperability between RIs and universities that would enable collaboration with companies.

RIs and universities lack administration.

Without prior problem identification and description, the company asks RI for consulting.

The company recognizes the importance of research and suggests collaboration with RI in joint projects.

RI contacts the company, and Rl's knowledge benefits the company. The company detects problems that cannot be solved by itself and uses the RI solutions.

There is collaboration among the company, RI, and "spin-off"

Adapted according to Cigler et al. (2008) companies.

\section{Company performance}

The profits based on new investment funds increased.

Realized investments increased.

Market value increased.

Added value per employee increased.

Average number of employees increased.

Net revenue from sales increased.

Financial sources are more accessible.

Adapted

according to

Kaplan and

Norton (2000)

Percentage of capital increased.

Exports of goods and services increased.

Sales increased.

Notes: (1) Likert scale 1-7; 1-strongly disagree, 7-strongly agree; (2) R\&D = research and development; (3) RI = research institute

Source: Authors

In PAF (Warner, 2008), the analysis of the data structure focuses on shared variance and not on sources of error that are unique to individual measurements. We applied PAF in two steps (Rašič, 2015). We determined the PAF method for assessing the communalities first, followed by the Varimax rotation of the factor loadings. Based on the results of the factor analysis, limits for the inclusion of variables in the factor model were determined at the value of communalities 0.40 (Field, 2005). We 
excluded from the model any variables in which less than $40 \%$ of the variance was accounted for. For easier factor interpretation, we applied the Varimax method, where the rotated factors were independent from each other. We saved factor scores in the SPSS program and thus created new variables. When answering the research question using the regression analysis, we also met the criterion that the independent variables not be correlated.

\section{Results}

Table 2 shows that the highest mean of agreement regarding the statements that describe the establishment of scientists' collaboration with companies and the obstacles to it was achieved for the statements "there is a lack of interoperability between research institutes (RIS) and universities that would enable collaboration with companies" and "Rls and universities lack administration"; however, respondents only slightly agreed with these statements (mean $=4.8$ ).

Table 2

Descriptive statistics about knowledge

\begin{tabular}{|c|c|c|}
\hline Statement & Mean & $\begin{array}{l}\text { Standard } \\
\text { Deviation }\end{array}$ \\
\hline Knowledge is oriented to R\&D. & 3.3 & 1.8 \\
\hline $\begin{array}{l}\text { Joint R\&D projects of universities and companies are useful for } \\
\text { marketing. }\end{array}$ & 3.5 & 1.9 \\
\hline Financing of all project phases is uncertain. & 4.4 & 2.0 \\
\hline $\begin{array}{l}\text { The company lacks financial resources for collaboration with } \\
\text { universities. }\end{array}$ & 4.4 & 2.1 \\
\hline Governmental policy in the field of research is unclear. & 4.7 & 1.9 \\
\hline $\begin{array}{l}\text { There is a lack of state incentives for scientists' collaboration with } \\
\text { companies. }\end{array}$ & 4.6 & 2.1 \\
\hline Slovenia is overly oriented to basic research. & 4.5 & 2.0 \\
\hline $\begin{array}{l}\text { Habilitation rules of RIs and universities in Slovenia do not motivate } \\
\text { collaboration with companies. }\end{array}$ & 4.6 & 2.0 \\
\hline $\begin{array}{l}\text { There is a lack of researchers in RIs and universities that would meet } \\
\text { the specific needs of projects for companies in Slovenia. }\end{array}$ & 4.7 & 2.0 \\
\hline $\begin{array}{l}\text { There is a lack of interoperability between RIs and universities that } \\
\text { would enable collaboration with companies. }\end{array}$ & 4.8 & 2.0 \\
\hline RIs and universities lack administration. & 4.8 & 2.0 \\
\hline $\begin{array}{l}\text { Without prior problem identification and description, the company } \\
\text { asks RI for consulting. }\end{array}$ & 3.6 & 2.0 \\
\hline $\begin{array}{l}\text { The company recognizes the importance of research and suggests } \\
\text { collaboration with } \mathrm{RI} \text { in joint projects. }\end{array}$ & 3.8 & 1.7 \\
\hline RI contacts the company, and Rl's knowledge benefits the company. & 3.5 & 1.6 \\
\hline $\begin{array}{l}\text { The company detects problems that cannot be solved by itself, and } \\
\text { uses the RI solutions. }\end{array}$ & 3.6 & 1.7 \\
\hline $\begin{array}{l}\text { There is collaboration among the company, RI, and "spin-off" } \\
\text { companies. }\end{array}$ & 3.3 & 1.7 \\
\hline
\end{tabular}

Notes: (1) Likert scale 1-7; 1-strongly disagree, 7-strongly agree; (2) R\&D = research and development; (3) RI = research institute

Source: Authors

On average, respondents also slightly agreed that there is a lack of researchers in RIs and universities that would meet the specific needs of projects for companies in Slovenia, governmental policy in the field of research is unclear, habilitation rules of Rls and universities in Slovenia do not motivate collaboration with companies, and there is a lack of state incentives for scientists' collaboration with companies. In 2013 
the number of researchers in higher education in Slovenia was low, at $8.2 \%$ (Stare et al., 2015, p. 40). With all other statements about establishment of scientists' collaboration with companies and the obstacles to it, the respondents on average neither agreed nor disagreed or even slightly disagreed.

Table 3 shows that, on average, respondents slightly disagreed with all statements about company performance.

Table 3

Descriptive statistics about company performance

\begin{tabular}{ll|l}
\hline Statement & Mean & $\begin{array}{l}\text { Standard } \\
\text { Deviation }\end{array}$ \\
\hline The profits based on new investment funds increased. & 3.2 & 1.8 \\
\hline Realized investments increased. & 3.3 & 1.7 \\
\hline Market value increased. & 3.3 & 1.7 \\
\hline Added value per employee increased. & 3.3 & 1.6 \\
\hline Average number of employees increased. & 3.1 & 1.6 \\
\hline Net revenue from sales increased. & 3.2 & 1.6 \\
\hline Financial sources are more accessible. & 3.0 & 1.5 \\
\hline Percentage of capital increased. & 3.2 & 1.6 \\
\hline Exports of goods and services increased. & 3.1 & 1.6 \\
\hline Sales increased. & 3.2 & 1.6 \\
\hline Note:
\end{tabular}

Note: 1 = strongly disagree, 2 = disagree, 3 = slightly disagree, 4 = neither agree nor disagree, 5 = slightly agree, $6=$ strongly agree, and 7 = totally agree

Source: Authors

The results of factor analysis for company performance indicated that $78 \%$ of the variance is accounted for by only one factor. The structure of the factor "Company performance" is presented in Table 4.

The results of Bartlett's test of sphericity $(p<0.05)$ and the value of KMO measure of sampling adequacy $(\mathrm{KMO}=0.917$ for knowledge, $\mathrm{KMO}=0.950$ for company performance) show the suitability of the data for factor analysis.

As the values of communalities of the variables "Knowledge is oriented to R\&D" and "Joint R\&D projects of universities and companies are useful for marketing," were lower than 0.4 , these two variables were excluded from further analysis.

The results of the factor analysis for knowledge indicated that $76 \%$ of the variance was accounted for by two factors:

- Obstacles to the establishment of scientists' collaboration with companies ( $48 \%$ of variance), and

- Establishment of scientists' collaboration with companies ( $28 \%$ of variance).

Based on factor loadings after Varimax rotation, the structure of the factors of knowledge "Obstacles to the establishment of scientists' collaboration with companies" (Factor 1) and "Establishment of scientists' collaboration with companies" (Factor 2) is presented in Table 4.

After saving factor scores as new variables, we performed a regression analysis to answer the research question. The results of the regression (Table 5) indicated that the regression coefficient of the obstacles to the establishment of scientists' collaboration with companies was -0.054 and was not significantly different from 0 ( $p$ $>0.05)$. The regression coefficient of the establishment of scientists' collaboration with companies was 0.549 and was significantly different from $0(p<0.001)$. 
Table 4

Factor loadings in the rotated factor matrix for knowledge Statement Factor 1 Factor 2

There is a lack of researchers in RIs and universities that would meet

the specific needs of projects for companies in Slovenia.

Governmental policy in the field of research is unclear. 0.889

Habilitation rules of RIs and universities in Slovenia do not motivate collaboration with companies.

0.884

Slovenia is overly oriented to basic research.

0.882

0.870

There is a lack of state incentives for scientists' collaboration with

companies.

0.868

There is a lack of interoperability between RIs and universities that would enable collaboration with companies.

The company lacks financial resources for collaboration with

universities.

0.854

RIs and universities lack administration.

0.800

Financing of all project phases is uncertain.

0.770

RI contacts the company, and Rl's knowledge benefits the company.

The company detects problems that cannot be solved by itself and uses the RI solutions.

Financing of all project phases is uncertain.

The company recognizes the importance of research and suggests

collaboration with RI in joint projects.

Without prior problem identification and description, the company asks RI for consulting.

Note: Factor 1: Obstacles to the establishment of scientists' collaboration with companies,

Factor 2: Establishment of scientists' collaboration with companies

Source: Authors

Table 5

Effect of knowledge on company performance

\begin{tabular}{|c|c|c|c|c|c|}
\hline \multirow[t]{2}{*}{ Parameter / Variable } & \multicolumn{2}{|c|}{$\begin{array}{r}\text { Unstandardized } \\
\text { Coefficients }\end{array}$} & \multicolumn{3}{|c|}{ Standardized Coefficients } \\
\hline & B & Std. Error & Beta & $t$ & $p$ \\
\hline Constant & 1.517 & 0.235 & & 6.466 & 0.000 \\
\hline $\begin{array}{l}\text { Obstacles to the establishment of } \\
\text { scientists' collaboration with } \\
\text { companies }\end{array}$ & -0.054 & 0.047 & -0.065 & -1.154 & 0.249 \\
\hline $\begin{array}{l}\text { Establishment of scientists' } \\
\text { collaboration with companies }\end{array}$ & 0.549 & 0.055 & 0.566 & 10.012 & $0.000 * * *$ \\
\hline
\end{tabular}

\section{Discussion}

Knowledge is a complex phenomenon that cannot be accounted for by one indicator only. It is also the key mechanism and a combination of new information and communication technologies. It has brought about a radical change in the manufacturing process, in the organization of work and innovation, and particularly in research, which present a growing part of the value of goods and services, education, and training (Slovenian Research Agency, 2002). At the micro-economic level, knowledge includes the variables describing the establishment of cooperation with companies and obstacles to the establishment of collaboration with companies. By observing the obstacles to the establishment of scientists' 
collaboration with companies, the results of the survey among companies in Slovenia showed that the interoperability of research institutes and universities that would enable collaboration with companies is not sufficient. On average, companies do not clearly recognize the importance of research, which hinders their suggestions for collaboration in several projects with research institutes and universities.

The results of the regression analysis helped answer the research question: the establishment of scientists' collaboration with companies has a positive effect on company performance on the micro-economic level in Slovenia, whereas the effect of the obstacles to the establishment of scientists' collaboration with companies on the company performance cannot be confirmed. Previous research showed that 99\% of companies and other organizations in Slovenia are micro, small, and midsized, while the research institutes and universities are tailored mostly for the big ones (Mulej, 2007). Except the few high-tech ones, the smaller enterprises need more handicraft skills than scientists' knowledge.

Following El-Namaki (2011), the technological characteristics of small-scale industry could be measured in terms of eight specific variables: economies of scale; the technological base; technological disparity; infrastructural base; learning; industry differentials; labor intensity; and linkage pattern. The above written variables can be used to determine the technological characteristics of a particular sector.

\section{Conclusion}

This paper does not cover the measurement of technology research and innovation-two components of the triangle of research. It does also not deal with the effect of areas of knowledge at the macroeconomic level. It presents only a part of the requisitely holistic research, which conceptualizes and empirically verifies individual variables covering the company performance as well as the quality of life (Rašič, 2015).

Regarding the knowledge factors, the research results indicate that the establishment of scientists' collaboration with companies has a statistically significant positive impact on companies' performance. Based on the survey performed among small and medium-sized companies in Slovenia in 2013, the establishment of scientists' collaboration with companies includes collaboration between companies and research institutes, companies' recognition of the importance of research and therefore interest in the research institutes, benefits of the research institutes' knowledge to companies, detection of companies' problems and use of the research institutes' solutions, and collaboration among companies, research institutes, and "spin-off" companies. Furthermore, the economic growth at the microeconomic level defined as company performance includes the increase of the profits based on new investment funds, realized investments, value on the market, added value per employee, average number of employees, net revenue from sales, percentage of capital, exports of goods and services, sales, and accessible financial resources.

In order to strengthen research cooperation, measures to be included in the practice of governments and companies include: (i) solicitation of public and corporative (co-)financing of research projects; (ii) subsidies from public resources of employment of researchers in enterprises; (iii) subsidies from public resources of project-based combined employment in universities or other research organizations and enterprises; and (iv) subsidies from public resources of projects in which bigger enterprises attract smaller ones, too. Such measures directly value the decisive persons to provide the support for research. 
Further research could be oriented toward the common synergy index, such as the knowledge triangle, which would include technology research, innovativeness, and knowledge.

\section{References}

1. AJPES (2012), "iBON Business Community", available at http://www2.ibon.com/Default.aspx?/ (13 July 2013)

2. APEC (2000), "Towards Knowledge-Based Economies in APEC", available at http://www.isr.gov.au/library/contentlibrary /NEBTowardsKBEsummary.doc (13 July 2013)

3. Borell-Damian, L., Morais R., Smith, J. H. (2014), University-business collaborative research: Goals, outcomes and new assessment tools, The EUIMA collaborative research project report, Brussels, European University Association.

4. Cigler, G., Drnovšek, M., Lukšič, P., Orbanić, A., Peperko, A., Potočnik, P., Sterle, B. (2008), Ciljni raziskovalni projekt, šifra: V5-0251, Analiza prenosa znanja $\vee$ gospodarstvo po znanstvenoraziskovalnih področjih, Zaključno poročilo (Targeted research project, code: V5-0251, Analysis of knowledge transfer to the economy by scientific fields, Final report), Ljubljana, Institute of Mathematics, Physics and Mechanics.

5. Costanza, R., Hart, M., Posner, S., Talberth, J. (2009), Beyond GDP: The need for the new measures of progress, Boston, University of Boston.

6. Council of the European Union (2007), Competitiveness (Internal Market, Industry and Research), C/07/151, $11155 / 07$ (151), Luxembourg, Council of the European Union.

7. Council of the European Union (2008), Brussels European Council 13/14 March 2008: Presidency Conclusions, 7652/1/08, Brussels, Council of the European Union.

8. EIT (2008), The European Institute of Technology, available at http://eit.europa.eu/ (13 July 2010)

9. El-Namaki, S. (2011), "Developing and promoting technology and technical skills in small-scale rural manufacturing enterprises", available at http://www.fao.org/docrep/s8380e/s8380e0b.htm/ (25 November 2015)

10. Etzkowitz, H. (2002), The Triple Helix of University-Industry-Government Implications for Policy and Evaluation, Stockholm, Social Policy Institute.

11. Etzkowitz, H. (2008), The Triple Helix: University-Industry-Government in action, London, Routledge.

12. European Commission (2006), European Trend Chart on Innovation: Annual Innovation Policy Trends and Appraisal Report, Sweden, European Commission.

13. European Commission (2008), A more research-intensive and integrated European Research Area: Science, Technology and Competitiveness key figures report 2008-2009, Brussels, Directorate-General for Research.

14. European Parliament (2011), "Report on GDP and beyond-Measuring progress in a changing world", available at http://www.europarl.europa.eu/sides/getDoc.do?pubRef=//EP//TEXT+REPORT+A7-2011-0175+0+DOC+XML+VO//EN (15 May 2014)

15. European Research Advisory Board (2007), "Energising Europe's Knowledge Triangle of Research, Education and Innovation through the Structural Funds", available at https://ec.europa.eu/research/eurab/pdf/eurab_07_010_advice_energising_euro pe_knowledge_triangle_april07_en.pdf (1 1 February 2016) 
16. European Union (2010), Investing in Europe's future: Fifth report on economic, social and territorial cohesion, Brussels, European Commission, Directorate General for Regional Policy.

17. Eurostat (2008), Eurostat Regional yearbook 2008, available at http://epp.eurostat.ec.europa.eu/cac he/ITY OFFPUB/KS-HA-08-001/EN/KS-HA-08001-EN.PDF (14 June 2012)

18. Field, A. (2005), Discovering Statistics using SPSS, $2^{\text {nd }}$ ed., London, Sage Publications.

19. Guellec, D. (1996), "Knowledge, skills and growth: some economics issues", STI Review, Vol. 18, No. 1, pp. 1-18.

20. Kaplan, R. S., Norton, D. P. (1996), The Balanced Scorecard: Translating Strategy into Action, Boston, Harvard Business School Press.

21. Kaplan, R. S., Norton, D. P. (2000), Uravnoteženi system kazalnikov: preoblikovanje strategije $\vee$ dejanja (The Balanced Scorecard: Translating Strategy into Action, in Slovenian), Ljubljana, Gospodarski vestnik.

22. Kotnik, P. (2005), "Innovative and R\&D activities of Slovenian firms", in Prašnikar, J. (Ed.), Medium-sized firms and economic growth, Nova Science Publishers, New York, pp. 157-168.

23. Mulej, M. (2007), Inoviranje navad države in manjših podjetij z invencijami iz raziskovalnih organizacij (Innovating the habits of state and small companies with inventions from research organizations, in Slovenian), Koper, Faculty of Management.

24. OECD (1996), The Knowledge-based Economy, Paris, OECD.

25. OECD (2000), Science and technology outlook, Brussels, OECD, Industry science relations.

26. OECD (2001 a), "The new economy: Beyond the hype, final report on the OECD Growth project", available at http://www.oecd.org/subject/growth/ (30 November 2013)

27. OECD (2001b), "Science, Technology and Industry Scoreboard: Towards a Knowledge-based Economy", available at http://www1.oecd.org/publications/e-book/92-2001-04-1-2987/ (13 October 2013) 28. OECD (2015), "Better Life Index", available at http://www.oecdbetterlifeindex.org (21 August 2015)

29. Pavlin, S., Svetlik, I. (2005), "Nasproti merjenju znanja (Towards Knowledge Measurement, in Slovenian)", Teorija in praksa, Vol. 42, No. 4-6, pp. 719-729.

30. Pezdir, R. (2004), "Tehnološko sodelovanje med znanostjo in gospodarstvom ((Technological cooperation between science and industry)", in Mali, F. (Ed.), Mehanizmi in ukrepi za prenos znanja iz akademske in raziskovalne sfere $v$ luči novih inovacijskih paradigem-stanje in trendi razvoja $\vee$ Sloveniji glede na razvite države Evropske unije (Mechanisms and measures for the transfer of knowledge from the academic and research community in the light of new innovation paradigm-state and development trends in Slovenia compared to the developed countries of the EU, in Slovenian), University of Ljubljana, Faculty of Social Sciences, Ljubljana, pp. 245-256.

31.Polt, W., Rammer, C., Schartinger, D., Gassler, H., Schibany, A. (2001), "Benchmarking industry-science relations: the role of framework conditions", Science and Public Policy, Vol. 28, No. 4, pp. 247-258.

32. Rašič, K. (2015), Sistem indikatorjev tehnično-tehnoloških raziskav, inovativnosti in znanja na primeru tranzicijskega gospodarstva (The System of indicators of technological research, innovativeness and knowledge: the case of transitional 
economy, in Slovenian), Doctoral Dissertation, Maribor, University of Maribor, Faculty of Economics and Business.

33. Ribeiro, L. C., Ruiz, R. M., Bernardes, A. T., da Motta e Albuquerque, E. (2010), "Modelling Economic Growth Fuelled by Science and Technology", Estudos Econômicos, Vol. 40, No. 2, pp. 319-340.

34. Slovenian Research Agency (2002), "Izhodišča ciljnega raziskovalnega programa Konkurenčnost Slovenije 2001-2006 (The basis of the goal research project The competitiveness of Slovenia 2001-2006, in Slovenian)", available at http://www.arrs.gov.si/sl/razpisi/02/inc/izhodisca.pdf (21 June 2015)

35. Stare, M., Vidrih, A. (2015), "Inovacijska sposobnost (Innovation Capacity, in Slovenian)", in Kmet Zupančič, R. (Ed.), Poročilo o razvoju 2015 (Development Report 2015, in Slovenian), UMAR, Ljubljana, pp. 39-42.

36. Steiner, G., Risopoulos, F., Mulej, M. (2015), "Social responsibility and citizen-driven innovation in sustainably mastering global socio-economic crises", Systems Research and Behavioral Science, Vol. 32, No. 2, pp. 160-167.

37. Stiglitz, J. (2009), "Towards a better measure of well-being", The Financial Times Limited, September 13, 2009, available at http://www.ft.com/cms/s/0/95b492a8a095-1 1 de-b9ef-001 44feabdc0.html\#axzz3dPaf0MOr (18 June 2015)

38. Stiglitz, J. E., Sen, A., Fitoussi, J. P. (2009), "Report by the Commission on the Measurement of Economic Performance and Social progress", available at http://www.insee.fr/fr/publications-et-services/dossiers_web/stiglitz/doccommission/RAPPORT_anglais.pdf (30 November 2015)

39. UNESCO (2008), "Education for All by 2015-Will we make it?", available at http://unesdoc.unesco.org/images/0015/001547/154743e.pdf (14 February 2013)

40. Warner, R. M. (2008), Applied statistics: from bivariate through multivariate techniques, Los Angeles, Sage Publications. 


\section{About the authors}

Katja Rašič holds a PhD in Economic and Business Sciences, and is a senior adviser at the Ministry of Infrastructure, Slovenia. She works as a technical assistance of European Commission for Cohesion policy and other structural funds for railway infrastructure and transport logistics projects. Her field of research focuses on the innovative processes, and indicators of economic growth and better quality of life on micro- and macro-economic level. Author can be contacted at katja.rasic@gov.si

Matjaž Mulej, Emeritus Professor of Systems and Innovation Theory, PhD in Economics (Systems Theory), PhD in Management (Innovation Management), author of Dialectical Systems Theory and of Innovative Business in catching-up countries. Publications: beyond 1.700 in close to 50 countries, about 60 (mostly edited) books and proceedings, recently about social responsibility. Several hundred citations. Factor +30 in ResearchGate data, with beyond $6 \mathrm{k}$ visits and down-loadings. Member of three international academies of science, former president of the International Academy for Systems and Cybernetic Sciences. Visiting professor abroad for 15 semesters. Dean and vice-rector in 1979-1983, University of Maribor. Author can be contacted at matjaz.mulej@um.si

Vesna Čančer holds a PhD in Economic and Business Sciences, and is an Associate Professor of Quantitative Methods in Business Science at the University of Maribor's Faculty of Economics and Business (UM FEB). Her research focuses primarily on decision analysis, creative problem solving and research methods, together with their interdisciplinary applications. She is Head of the Department of Quantitative Economic Analysis at UM FEB and Editor-in-Chief of the journal of contemporary issues in economics and business Naše gospodarstvo/Our Economy. Author can be contacted at vesna.cancer@um.si 